\title{
Genetic Transformation of Transcription Factor (35S-oshox4) Gene into Rice Genome and Transformant Analysis of hpt Gene by PCR and Hygromycin Resistance Test
}

\author{
ENUNG SRI MULYANINGSIH ${ }^{1, \vartheta}$, REGY HERMAWAN ${ }^{2}$, INEZ HORTENZE SLAMET-LOEDIN ${ }^{1}$ \\ ${ }^{1}$ Research Centre for Biotechnology, Indonesian Institute of Sciences (LIPI), Cibinong-Bogor 16911 \\ ${ }^{2}$ Department of Biochemistry, Faculty of Mathematics and Natural Sciences, Bogor Agricultural University (IPB) Bogor 16680.
}

Received: $8^{\text {th }}$ November 2008. Accepted: $20^{\text {th }}$ December 2008.

\begin{abstract}
Global warming, climate change and crop extensification in marginal dryland areas are related to long dry season and water deficit. The water availability is an important factor in improving plant production. Application of drought tolerant rice cultivars is one of several options that might be used. Genetic engineering at the level of transcription factors is particularly promising strategy to develop drought tolerant rice varieties. Transcription factors regulate a wide range of target genes in which of them contribute to stress tolerance. HD Zip genes are transcription factor that potential in the adaptation of plants to some environment stresses including water deficit. HD-ZIP oshox4 (oryza sativa homeobox) gene controlled by $35 \mathrm{~S}$ promotor is inserted into pCAMBIA 1300 vector with hpt (hygromycin) gene as a selectable marker. The aim of this research is to obtain transgenic rice plant from transformation with 35S-oshox4 plasmid, segregation analysis of marker gene (hpt) by PCR method at $T_{0}$ and $T_{1}$ generation, and hygromycin resistance analysis of seeds. Recombinant plasmid was transformed into rice genome of IRAT 112 and rojolele cultivars using Agrobacterium tumefaciens. The results showed that transformation efficiency of IRAT 112 was $5.7-13.6 \%$ and $26-66,7 \%$ for rojolele. While regeneration efficiency for IRAT 112 is $4.7-43.7 \%$ and $23-44.1 \%$ for rojolele. The result of hygromycin resistance test at $T_{1}$ seeds were obtained 14 lines $\mathrm{cv}$. rojolele segregation Mendelian for $h p t$ gene. The PCR analysis using specific primers for $h p t$ gene at the parent $\left(T_{0}\right)$ from 14 lines showed that 7 lines contain the gene. At the second generation $\left(T_{1}\right)$, PCR analysis using hpt primers showed that 3 from 4 lines were followed Mendelian segregation pattern by the presence of specific band.
\end{abstract}

(c) 2009 Biodiversitas, Journal of Biological Diversity

Key words: HD-Zip oshox (oryza sativa homeobox), 35S-oshox4, hpt, Agrobacterium tumefaciens, PCR.

\section{INTRODUCTION}

Global warming, unpredictable climate change and crop extensification in marginal dryland area are related to long dry season and deficit water. Water availability is a major limiting factor for increase of food production. According to Gorantla et al. (2005), rice crop consume about $90 \%$ from total water that is utilized for agricultural need at Asian. About $80 \%$ of total rice crop need water because most of rice crops are irrigated rice field (55\%) and rain field (25\%). Water deficit caused stress for plant. Water deficit will be major problem which influence global productivity. The drought stress effect could be lost of productivity until more than $70 \%$ (Bray et al., 2000).

In attempt to dissolve of that problem, drought tolerance plant was used. Drought tolerance plant

\footnotetext{
- Corresponding address:

JI. Raya Bogor Km.46 Cibinong-Bogor 16911

Tel. +62-21-8754587; Fax. +62-21-8754588

e-mail: enungf@yahoo.com
}

could be obtained by some technique, such as genetic transformation and plant breeding. The important thing in creating this plant is understanding drought tolerant. Drought tolerance character is encoded by many genes. Shinozaki and Yamaguchi Shinozaki $(1997,2007)$ classified this into two groups; first, protein that most probably function in drought (protection factors of macromolecules, enzymes for osmolyte biosynthesis, detoxification enzymes, water channel, transporter); and second is regulatory protein (protein kinase, protein phosphatase, enzyme phospholipid metabolism and transcription factors).

Genetic Transformation at transcription factor level will enable to obtain of drought tolerant rice, because transcription factor regulate other genes that responsible to drought tolerance. Some of transcription factors have been characterized, for example DREB (dehydration responds element binding) (Yamaguchi Shinozaki and Shinozaki, 2001; Sakuma et al., 2006), SNAC (stress responsive NAC1) (Hu et al., 2006), and HD Zip (Homeodomain leucine zipper) (Meijer et al., 1997; Deng et al., 2002). The over expression of these gene in some plants 
caused increase of drought tolerance (Scarpella et al., 2005; Hu et al., 2006).

HD Zip genes were reported to be related with adaptation and development of plants under stressful environment. HD Zip genes in rice plant are classified into family I, II, III that consist of $33 \mathrm{HD}$ Zip genes oshox (oryza sativa homeobox) which is spread in 12 chromosomes. There are only two genes oshox have been identified which is oshox1 (HD Zip II) and oshox4 (HD Zip I) that regulate by drought stress. The expression of genes are up and down regulated under drought situation and depend on plant sensitivity to drought (Purwantomo, 2007; Agalou et al., 2008).

Research Centre for Biotechnology LIPI have obtained first generation $\left(T_{0}\right)$ of putative transgenic rice from rojolele and IRAT 112 cultivars that transformed with transcription factor HD Zip oshox4 gene. This gene is controlled with constitutive promotor CaMV 35S (cauliflower mozaic virus). Cassette 35S oshox4 and terminator were inserted in PCAMBIA 1300 plasmid on Hind/II site. Hygromycin phosphotransferase (hpt) gene to generate hygromycin antibiotic resistance for transformant selection. The recombinant plasmid was designated as 35S oshox4 and transformed into javanica cultivar (rojolele) and indica cultivar (IRAT 112) using Agrobacterium tumefaciens (A. tumefaciens).

The aim of research is to obtain transgenic rice plant transformed with 35S-oshox4 plasmid, to evaluate lines containing hpt gene based on PCR analysis, to evaluate expression and segregation pattern of $h p t$ using bioassay hygromycin seeds.

\section{MATERIALS AND METHODS}

Rice cultivar of javanica rojolele and indica IRAT 112 transformed by 35 S-oshox 4 plasmid were made available Dr. A.H Meijer and Dr Pieter B.F. Ouwerkerk (Institute of Molecular Plant Science, Leiden University). Strain A. tumefaciens using EHA 105 resistance to rifampycin antibiotic. Analysis transformant at first $\left(T_{0}\right)$ and second $\left(T_{1}\right)$ generation plant population that property RC Biotechnology LIPI. Materials for DNA isolation comprise: isolation buffer [lysis buffer (Tris $\mathrm{HCl}$ pH $7.50 .2 \mathrm{~m}$, EDTA $0.05 \mathrm{M}$, $\mathrm{NaCl} 2 \mathrm{~m}$, and CTAB 2\%)]; extraction buffer [extraction buffer (sorbitol $0.35 \mathrm{~m}$, Tris $\mathrm{HCl} \mathrm{pH} 7.50 .1$ $\mathrm{m}$, and EDTA $5 \mathrm{mM}$ ); sarkosil $5 \%], \mathrm{N}_{2}$ liquid, chloroform: isoamylalcohol (24:1), isopropanol, ethanol 70\%, TE buffer (Tris HCL pH $8.010 \mathrm{mM}$ and EDTA PH $8.01 \mathrm{mM}$ ). Material used for PCR reaction: plant DNA, PCR buffer, dNTPs, primary gos-5 forward and reverse (5'CCGACCTCGAGGACATCGG CAACAG 3') and (5' GCCGAGAGCAGCAGGAACTT GACAGG 3'), primary hpt forward and reverse (5' GATGCCTCCGCTCGAAGTAGCG 3') and (5' GCATCTCCCGCCCGTGCAC 3 '), $\mathrm{dH}_{2} \mathrm{O}$, agarose gel and Tris Boric Acid EDTA buffer (TBE). Material those were utilized for hygromycin test: $50 \mathrm{mg} / \mathrm{mL}$ hygromycin, sterile aquadest, sterile filter paper, alcohol $70 \%$, benlate $3 \%$, and $\mathrm{NH}_{4} \mathrm{ClO} 2 \%$.

\section{Genetic transformation into rice genome}

Recombinant plasmid 35S-oshox4 was inserted into $A$. tumefaciens strain EHA 105 by electroporation method. Bacteria were cultured in solid $A B$ medium which contained rifampycin $20 \mathrm{mg} / \mathrm{L}$ and kanamycin $50 \mathrm{mg} / \mathrm{L}$. Bacteria culture were then incubated at $28^{\circ} \mathrm{C}$ for 3 days. This culture was used for cocultivation.

Transformation into embriogenic callus using A.tumefaciens was perfomed following methods as described elsewhere (Hiei et al., 1994). $A$. tumefaciens was subcultured in AAM liquid medium without antibiotic and shaked to 1-2 hours until $\mathrm{OD}_{600}$ : $0,4-0,5$. The embryogenic callus from cv. rojolele and cV. IRAT 112 were induced in IK3 medium (LS media that contains 2,4-D $2,5 \mathrm{mg} / \mathrm{L}$ and solidified with phytagel 0,2\%) (Slamet-Loedin et al., 1997). Callus induction was done for 2 weeks in dark room. For infection, callus is soaked in A. tumefaciens culture up to 30 minutes. Callus and bacteria at co-cultivation in IK3-AS medium (IK3 contain of acetosyringone 100 $\mathrm{mM}$ ) and incubation on $25^{\circ} \mathrm{C}$ for 3 days in dark. After co cultivation, callus washed by cefotaxime $400 \mathrm{mg} / \mathrm{L}$ and cultured at $\mathrm{IK} \mathrm{C}_{250} \mathrm{H}_{50}$ as selection medium (IK3 contain of cefotaxime $250 \mathrm{mg} / \mathrm{L}$ and hygromycin 50 $\mathrm{mg} / \mathrm{L})$ for 2 weeks. Callus were subculture at second selection medium for two weeks $I \mathrm{~K} 3 \mathrm{C}_{50} \mathrm{H}_{50}$. The resistance callus to hygromycin were subculture into R3B medium for regeneration (LS + IAA $0,5 \mathrm{mg} / \mathrm{L}+$ BAP $0,3 \mathrm{mg} / \mathrm{L}$ and phytagel 0,5\%) (Slamet-Loedin et al., 1997). Obtained plantlets were moved into MS medium without hormone. The normal plantlets were acclimatized into soil medium at greenhouse.

\section{DNA isolation for PCR}

DNA Isolation for PCR from leaf (2-3 weeks plant). Isolation method as follows: leaf $5 \mathrm{~cm}$ length was inserted put into microtube $1.5 \mathrm{~mL}$, add with $\mathrm{N}_{2}$ liquid then grinded and added with $750 \mu \mathrm{L}$ isolation buffer. The mixtures were then incubated at $65^{\circ} \mathrm{C}$ for 1 hour. Later tube is added $750 \mu \mathrm{L}$ chloroform: isoamylalchohol (24:1) and centrifuge 5 minutes at $12.000 \mathrm{rpm}, 4^{\circ} \mathrm{C}$. The supernatant was transferred into new tube and added with $400 \mu \mathrm{L}$ isopropanol (cold), then centrifuge for 6 minutes at $12.000 \mathrm{rpm}$ on $4^{\circ} \mathrm{C}$. Supernatant was discarded and pellet was washed by ethanol $70 \%$ then centrifuge at 12.000 rpm on $4^{\circ} \mathrm{C}$ for 3 minutes. Supernatant is discarded and pellet in tubes dried. Palette from DNA was dissolved by TE $50 \mu \mathrm{L}$ and stored at $20^{\circ} \mathrm{C}$.

\section{$P C R$ analysis at $T_{0}$ plant}

Plants DNA were obtained from $T_{0}$ and $T_{1}$ population. PCR reaction is enclosed with primer gos$5 I$ as internal rice gene. Negative control using DNA plant controls (without transformation) and water, 
while positive control uses 35S-oshox4 plasmid. PCR reaction mixtures were as follows: 1x PCR buffer, dNTP $0.05 \mathrm{mM}$, Taq Polymerase $0.05 \mathrm{u}$, primer 2. 5 $\mathrm{ng} / \mu \mathrm{L}$ gos -5 reverse and forward, primer $2.5 \mathrm{ng} / \mu \mathrm{L}$ hpt reverse and forward. PCR temperature and cycle it one denaturation cycle $\left(95^{\circ} \mathrm{C}, 10\right.$ minutes): 40 amplification cycles [denatures $95^{\circ} \mathrm{C} 1$ minute, annealing $55^{\circ} \mathrm{C} 1$ minute, synthesis $72^{\circ} \mathrm{C} 1$ minute]; $72^{\circ} \mathrm{C} 10$ minutes (final elongation); $4^{\circ} \mathrm{C}$ (store).

\section{Hygromycin test}

As many as 76 lines rice seed $T_{1}$ (planted 50 seeds for each line). Seeds was husked, washed with sterile aquadest and followed with alcohol $70 \%$ for 1 minute and washed with sterile aquadest. Seeds were then soaked with benlate $3 \%$ solution for 30 minutes and washed with sterile distilled water until clear. Finally, seeds were washed by $2 \% \mathrm{NH}_{4} \mathrm{ClO}$ for 30 minutes and rinsed with sterile distilled water for 5 minutes 10 times repeatedly at laminar air flow. Planted seed on sterile filter paper already been damped by $50 \mathrm{mg} / \mathrm{L}$ hygromycin. As for control, filter paper was just soaked with distilled water. Seed were placed in dark room to stimulate germination for 3 days, then moved under lamplight. The observation for seedling growth was carried out 2 weeks after plantation under following classification: normal seedling, abnormal and not grown (total number of normal seedling as amount of plant individual that using chi square to observe segregation pattern hpt gene). With opportunity point $5 \%$ and degree of freedom 1, therefore point chi square shall be smaller than $\mathrm{F}$ table $(3,84)$. It means pattern of segregations follow Mendelian which is 3: 1. Equation for tests chi square as follows:

$$
\chi^{2}=\frac{\left(\mathrm{O}_{i}-\mathrm{E}_{i)_{-}}{ }^{2}\right.}{\mathrm{E}_{i}}
$$

$\mathrm{O} \mathrm{i}=$ phenotype's observing point goes to $\mathrm{i}$.

$\mathrm{E} \mathrm{i}=$ phenotype's expectation point goes to $\mathrm{i}$.

\section{$P C R$ analysis of $T_{1}$ plant}

The normal seedling based on hygromycin test and segregation follows Mendelian (base on chi square) were planted on soil medium at greenhouse. Thirty seeds for each line were planted. DNA template for PCR reaction was isolated from leaf derived from 2-3 weeks old seedling according to the method described previously. PCR analysis was performed to confirm the presence of hpt gene on second generation plant $\left(T_{1}\right)$. PCR conditions were the same with $T_{0}$ analysis plant.

\section{RESULT AND DISCUSSION}

\section{Transformation into rice genome}

The transformation result into genome of two cultivar rice is presented at Table 1. Based on this table transformation efficiency and regeneration of cv. rojolele was higher than that of $\mathrm{cv}$. IRAT 112. The rojolele cultivar was relatively easy to form embryogenic callus than IRAT 112. Successful genetic transformation is related with embryogenic callus formation and plant regeneration system. According to $\mathrm{Ge}$ et al. (2006) callus induction and regeneration in rice tissue culture depend on a number of factors, such as genotype of the donor plant, type and physiology status of the explants, composition and concentration of the basal salt and organic components, and plant growth regulators in the culture medium. Among these factors, genotypic difference is the most important.

IRAT 112 Cultivar consists of indica rice. Most of the indica varieties belong to the group I, which these varieties have been quite recalcitrant cultivars (difficult for regeneration and transformation) in tissue culture and genetic transformation (Wunn et al., 1996; Zhang et al., 1998). Even success of transformation in indica rice was reported, but the results showed either low transformation efficiency or success only with very specific genotype (Zhang et al., 1997; Lin and Zhang, 2005). Therefore low efficiency and regeneration on IRAT 112 suggest the genotype of plant. The lower transformation efficiency on this genotype also occur in other cultivars such as IR72 and IR 64 each by level efficiencies $4.2 \%$ and 2.5 10.1\% (Aldemita and Hodges, 1996; Hiei et al., 2006; Khanna and Raina, 2002). Although recently reported that the transformation efficiency in ten indica rice cultivars could be obtained until $30 \%$ for each immature embryo with optimation things (Hiei et al., 2006). In the meantime on rojolele cultivar transformation efficiency and regeneration were higher than IRAT 112 because rojolele belong to javanica rice. This genotype (javanica) is easier for transformation and regeneration and is not a recalcitrant type.

Table 1. Summary of transformation using of recombinant plasmid 35S-oshox4 on cv. IRAT 112 and rojolele.

\begin{tabular}{|c|c|c|c|c|c|}
\hline 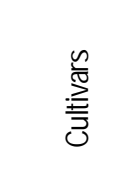 & 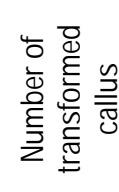 & 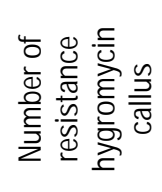 & 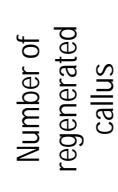 & 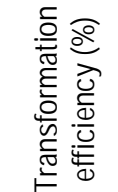 & 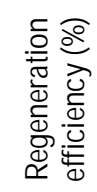 \\
\hline \multirow[t]{2}{*}{$\overline{\text { IRAT112 }}$} & 469 & 64 & 3 & 13,6 & 4,7 \\
\hline & 840 & 48 & 21 & 5,7 & 43,7 \\
\hline \multirow{3}{*}{ Rojolele } & 60 & 40 & 15 & 66,7 & 37,5 \\
\hline & 923 & 240 & 106 & 26,0 & 44,1 \\
\hline & 584 & 213 & 49 & 36,5 & 23,0 \\
\hline
\end{tabular}

\section{Hygromycin test on $T_{1}$ generation}

Hygromycin test on seed (the seed from $T_{0}$ plant) conducted to select a lot of number from lines putative transgenic. This analysis will reduce economic cost. The selection based on selectable 
marker could be an indicator for the presence other gene in the same of T-DNA. This examination is gone upon the expression of hpt gene as a selectable marker. With expression of $h p t$ gene be provided that target gene oshox 4 have also been integrated into rice genome. It is because hpt gene inserted on the same T-DNA with oshox4 gene (Figure 1).

Hygromycin is an antibiotic resistance marker commonly used for genetic transformation on monocotyledon plant especially Gramineae (Bashir et al., 2004). This antibiotic hampered synthesis of protein by troubles translocation so causes error translation on ribosome 80S (Bashir et al., 2004). Hygromycin phosphotransferase enzyme obtained from hpt gene could detoxificate of hygromycin B antibiotic (Rodriguez and Nottenburg, 2003) and catalyze phosphorrylation of hydroxyl group in hygromycin antibiotic so that this antibiotic not active and not poison for plant cell (Brasileiro and Aragao, 2001). The analysis result in the second generation $\left(T_{1}\right)$ and lines used for hygromycin test were presented on Table 2.

Water was used as control solution to observe seed germination from each line, whereas hygromycin solution as treatment solution. Seed which germinated and form normal seedling on hygromycin solution suggest that it may contain hpt expressed gene. Hygromycin was degraded by this plant, therefore it was not toxic and might not caused any trouble (Figure 2). Phenomenon of which hpt gene is integrated in the plant, genome but failed to express called gene silencing. There are three assumption of gene silencing which are cis inactivation, trans inactivation and co suppression. Cis-trans-inactivation occurred at transcription. Cis-inactivation occurs if 1 or many gene copies integrated on one locus in or near to genome sequent with high methylation. So, integrated gene will be methylation and not expression. Trans-inactivation occurred when insertion gene integrated on different locus and one of its integration experience cis- inactivation so becomes silencer to the homolog. Co- suppression happening on post transcription, processing, localization and or mRNA degradation while affluent mRNA production under strong promoter (Taylor, 1997). Other opinion was named of co-suppression occurred by involves coordinate silencing; sometimes coordinate reactivation from transgenic with endogenous homology or among 2 homolog transgenic (Matzke and Matzke, 1995).

Base on this experiment, 14 lines of plant expressing $h p t$ gene were obtained and the gene was segregated follows of Mendelian (3:1). These lines were from rojolele cultivar: $T_{1}$ B.4.2, $T_{1} B .6 .1, T_{1} B .9 .3$, $\mathrm{T}_{1 . B}$.17. 3, $\mathrm{T}_{1}$ B. 17.4, $\mathrm{T}_{1}$ B.18.1, $\mathrm{T}_{1 . B}$ B.28.1, $\mathrm{T}_{1 . C .2 .7}$,

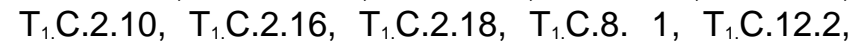
and $T_{1}$.C.13.1. The absence of hygromycin resistance from IRAT 112 cultivar might suggest that integrated gene was difficult to obtain, or the inserted gene was not expressed. PCR analysis to evaluate parent containing hygromycin from IRAT 112 was not performed.

\section{$P C R$ analysis of $T_{0}$ plant}

The aim of PCR analysis for hpt gene was to evaluate integration of the selectable marker and the segregation based on number of integrated plants. The 14 lines plant with Mendelian segregation based on hygromycin test from the second generation $\left(T_{1}\right)$ were planted in soil medium in green house with 30 seedlings for each line. Parallel with this activity, PCR analysis was done for the 14 plant as the parent $\left(T_{0}\right)$.

Table 2. Analysis of hpt gene expression on $T_{1}$ generation seed which transform with oshox4 gene.

\begin{tabular}{|c|c|c|c|c|c|c|}
\hline 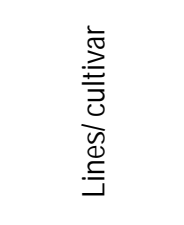 & 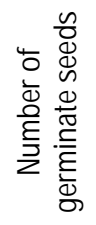 & 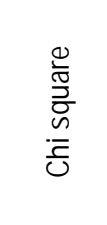 & 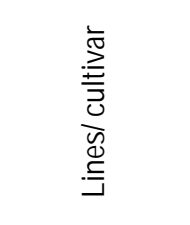 & 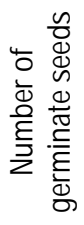 & 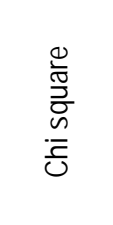 & 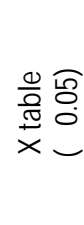 \\
\hline IRAT 112 & & & Rojolele & & & 3.84 \\
\hline T1.I.B.1.1 & 5 & 106.78 & T1.R.B.16.6 & 12 & 64.00 & \\
\hline T1.I.B.2.2 & 12 & 66.67 & T1.R.B.17.1 & 15 & 49.00 & \\
\hline T1.I.B.2.3 & 2 & 131.44 & T1.R.B.17.2 & 7 & 99.23 & \\
\hline T1.I.B.2.4 & 5 & 109.72 & T1.R.B.17.3 & 38 & 0.03 & \\
\hline T1.I.G.1.1 & 3 & 121.00 & T1.R.B.17.4 & 34 & 0.82 & \\
\hline T1.I.G.1.2 & 3 & 118.02 & T1.R.B.18.1 & 41 & 2.78 & \\
\hline T1.I.G.3.1 & 5 & 139.26 & T1.R.B.19.1 & 22 & 23.68 & \\
\hline T1.I.G.4.1 & 7 & 93.44 & T1.R.B.26.1 & 27 & 9.00 & \\
\hline T1.I.G.5.1 & 6 & 102.92 & T1.R.B.28.1 & 35 & 0.33 & \\
\hline T1.I.G.6.1 & 0 & 144.00 & T1.R.B.29.1 & 28 & 8.33 & \\
\hline T1.I.G.7.1 & 20 & 32.67 & T1.R.B.29.2 & 5 & 103.84 & \\
\hline T1.I.G.7.2 & 23 & 22.43 & T1.R.B.29.3 & 14 & 53.78 & \\
\hline T1.I.G.7.3 & 4 & 116.74 & T1.R.B.29.4 & 14 & 61.50 & \\
\hline T1.I.G.7.4 & 5 & 103.84 & T1.R.B.30.1 & 20 & 30.54 & \\
\hline T1.I.G.7.5 & 10 & 75.11 & T1.R.C.2.1 & 2 & 131.44 & \\
\hline T1.I.G.7.7 & 18 & 38.27 & T1.R.C.2.4 & 19 & 34.29 & \\
\hline T1.I.G.9.1 & 19 & 32.11 & T1.R.C.2.7 & 41 & 1.97 & \\
\hline T1.I.G.9.2 & 9 & 78.19 & T1.R.C.2.8 & 20 & 30.54 & \\
\hline T1.I.G.9.3 & 5 & 106.78 & T1.R.C.2.9 & 19 & 29.96 & \\
\hline T1.I.G.9.4 & 7 & 93.44 & T1.R.C.2.10 & 35 & 0.11 & \\
\hline T1.I.G.9.5 & 7 & 96.33 & T1.R.C.2.11 & 27 & 10.35 & \\
\hline T1.I.G.11.1 & 9 & 83.82 & T1.R.C.2.12 & 30 & 4.00 & \\
\hline T1.I.G.12.1 & 9 & 83.82 & T1.R.C.2.13 & 26 & 14.11 & \\
\hline T1.I.G.13.1 & 8 & 92.83 & T1.R.C.2.15 & 30 & 6.00 & \\
\hline \multirow{2}{*}{$\begin{array}{l}\text { Control } \\
\text { IRAT }\end{array}$} & 1 & 139.11 & T1.R.C.2.16 & 38 & 0.17 & \\
\hline & & & T1.R.C.2.18 & 37 & 0.03 & \\
\hline Rojolele & & & T1.R.C.4.1 & 26 & 12.58 & \\
\hline T1.R.A.1.5 & 19 & 34.29 & T1.R.C.4.2 & 29 & 5.44 & \\
\hline T1.R.B.2.1 & 31 & 4.51 & T1.R.C.4.3 & 19 & 27.86 & \\
\hline T1.R.B.4.1 & 21 & 27.00 & T1.R.C.6.2 & 24 & 16.00 & \\
\hline T1.R.B.4.2 & 33 & 2.16 & T1.R.C.7.1 & 28 & 7.11 & \\
\hline T1.R.B.6.1 & 32 & 2.46 & T1.R.C.8.1 & 39 & 0.24 & \\
\hline T1.R.B.8.1 & 19 & 25.79 & T1.R.C.8.2 & 22 & 21.78 & \\
\hline T1.R.B.8.2 & 20 & 28.44 & T1.R.C.9.1 & 29 & 6.54 & \\
\hline T1.R.B.8.3 & 17 & 42.46 & T1.R.C.10.1 & 13 & 64.03 & \\
\hline T1.R.B.8.4 & 8 & 84.26 & T1.R.C.12.2 & 39 & 0.24 & \\
\hline T1.R.B.9.1 & 28 & 8.33 & T1.R.C.13.1 & 43 & 3.23 & \\
\hline T1.R.B.9.3 & 33 & 1.53 & T1.R.C.15.1 & 30 & 4.00 & \\
\hline T1.R.B.11.1 & 16 & 46.86 & $\begin{array}{l}\text { Control } \\
\text { rojolele }\end{array}$ & 7 & 99.23 & \\
\hline
\end{tabular}

$\overline{\text { Note: bold is lines with Mendelian segregation. }}$ 

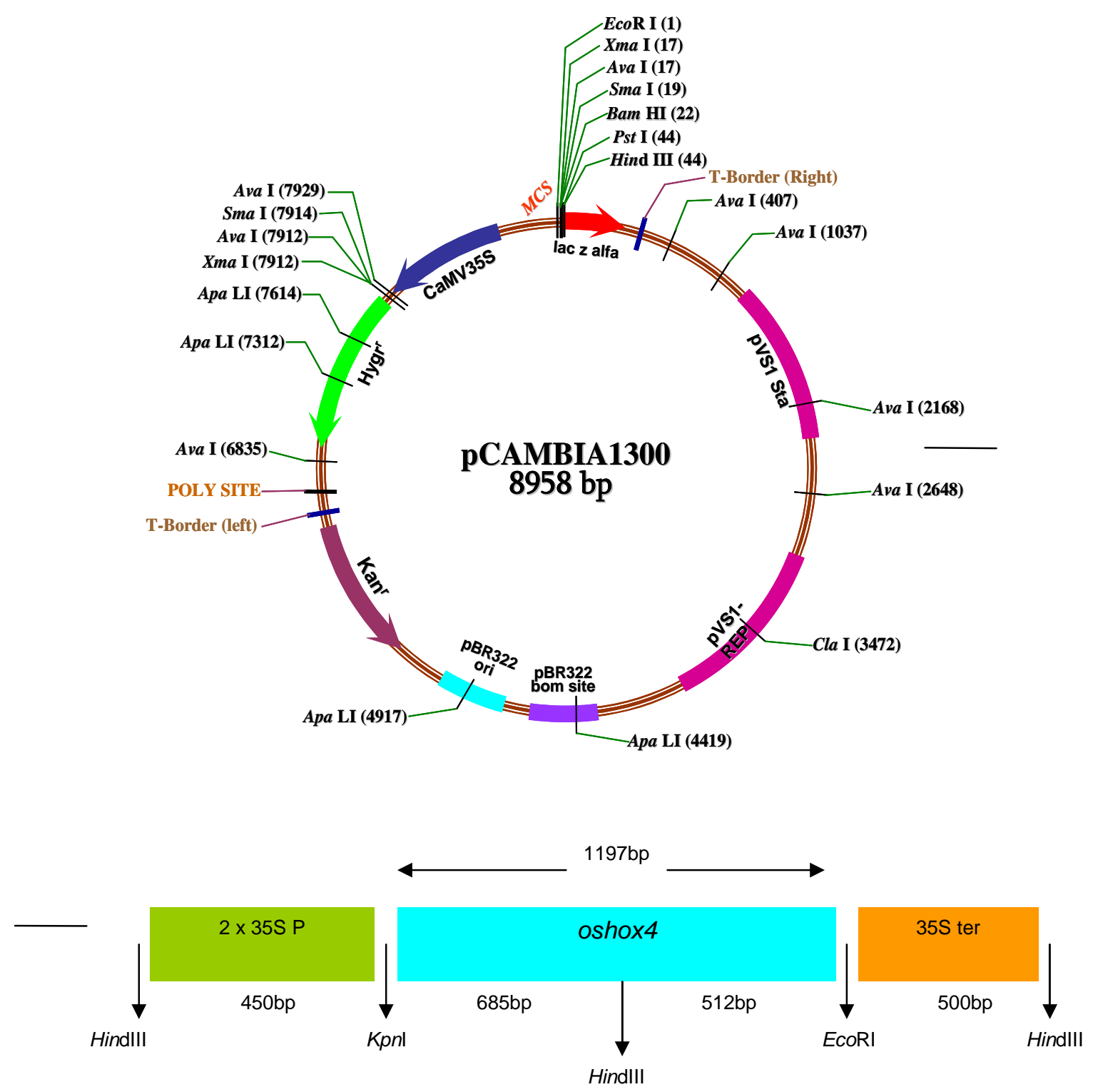

Figure 1. The recombinant vector construction $35 S$ Oshox 4 is utilized on the research.

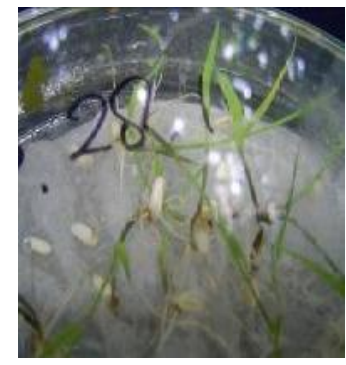

A

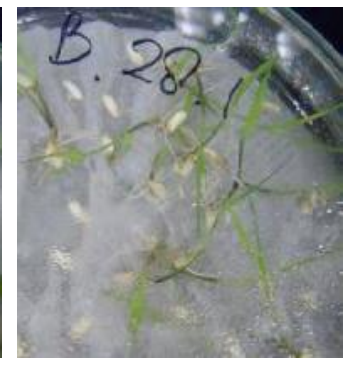

B

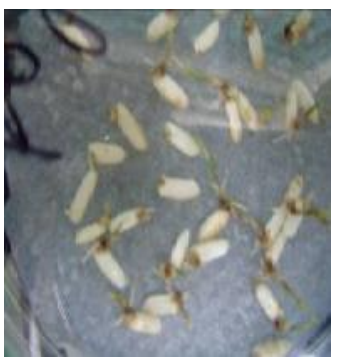

C

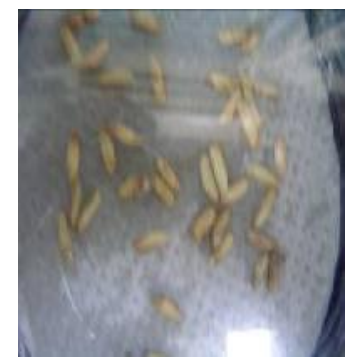

D

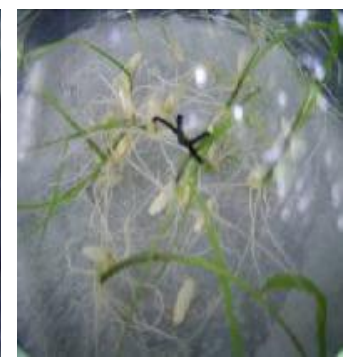

E

Figure 2. The hygromycin test at transformant seeds (T1). Resistance to hygromycin solution $(A)$, resistance to solution without hygromycin (B), transformant susceptible to hygromycin solution (C), seeds control in hygromycin solution (D), seeds control in solution without hygromycin (E). 

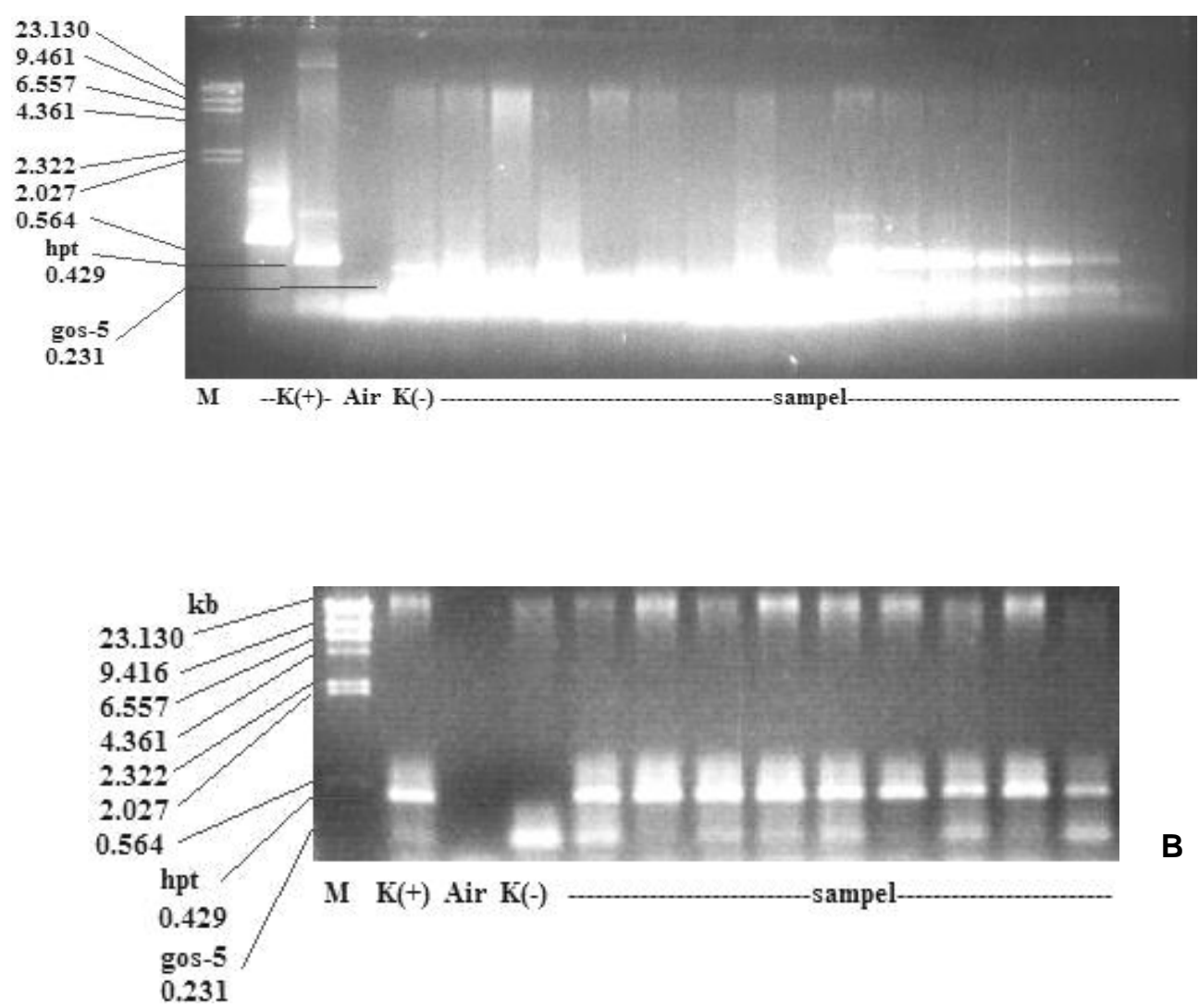

Figure 3. PCR result using hpt and gos -5 primers $\mathrm{A}$. first generation ( $\left.T_{0}\right)$, B. Second generation ( $\left.T 1\right)$.

Target gene to be amplificated is hpt and gos-5 with amplification product 429 and $231 \mathrm{bp}$ respectively. According to Meijer et al. (1991) one of gene in rice genome, so called gos -5 can be served as internal control. Internal control is subjected to confirm that DNA used fine. Proper DNA and PCR reaction were expected to give a $231 \mathrm{bp}$ length of PCR product in all samples including control (non transformation). The specific primer(s) was designed for amplification of specific gene(s). PCR analysis using hpt and gos-5 primers were done on 14 lines plant at first generation $\left(T_{0}\right)$. The analysis result showed that 7 lines plant $\mathrm{T}_{0}$ contain $h p t$ gene and amplification product of gos -5 were present in all lines tested. Those are $T_{0}$ C. $4.2, T_{0}$ C. $4.3, T_{0}$ C.8.1, $T_{0}$.C.9.1,

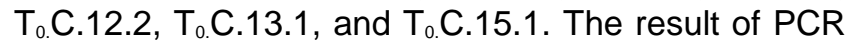
analysis on 14 lines $\left(T_{0}\right)$ was presented on Figure $3 \mathrm{~A}$.

The PCR result at second generation $\left(T_{1}\right)$ using hpt primers was done for 4 lines which were $T_{1}$.C.4.2, $\mathrm{T}_{1}$.C.4.3, $\mathrm{T}_{1}$.C.8.1 and $\mathrm{T}_{1}$.C.13.1. Tree of four lines were Mendelian segregation based on chi square tested. Those lines were $\mathrm{T}_{1}$. C.8.1, $\mathrm{T}_{1} . \mathrm{C} .13 .1$ and $\mathrm{T}_{1}$.C.4.2. The Mendelian segregation means that $h p t$ was integrated in rice genome and inherited on its generation. PCR result was presented on Figure 3B.

\section{CONCLUSION}

The transformation and regeneration for IRAT 112 callus cultivar using the recombinant plasmid $35 \mathrm{~S}$ Oshox4 is lower than that of rojolele. Transformation efficiency for IRAT 112 is $5.7-13.6 \%$ whereas 26$66.7 \%$ for rojolele. Regeneration of IRAT 112 callus between $4.7-43.7 \%$ and $23-44.1 \%$ for rojolele. Fourteen lines of rojolele cultivar at second generation (T1) were Mendelian segregation (3:1) for hpt gene. The lines are $\mathrm{T}_{1} \mathrm{~B} .4 .2, \mathrm{~T}_{1} \mathrm{~B} .6 .1, \mathrm{~T}_{1} \mathrm{~B} .9 .3$, $\mathrm{T}_{1 . B}$.17 3, $\mathrm{T}_{1 . B}$.17.4, $\mathrm{T}_{1}$ B.18.1, $\mathrm{T}_{1}$ B. 28.1, $\mathrm{T}_{1 . C .2 .7}$ $\mathrm{T}_{1}$ C.2.10, $\mathrm{T}_{1}$.C.2. 16, $\mathrm{T}_{1}$ C.2.18, $\mathrm{T}_{1}$ C.8. 1, $\mathrm{T}_{1}$.C. 12.2 and $T_{1}$ C.13.1. PCR analysis using hpt primers for 14 lines parents $\left(T_{0}\right)$ showed that 7 lines contain $h p t$ genes. The lines are $\mathrm{T}_{0 . C .4 .2}, \mathrm{~T}_{0}$.C.4.3, $\mathrm{T}_{0 . C .8 .1}$, $T_{0}$ C.9.1, $T_{0}$.C.12.2, $T_{0} . C .13 .1$, and $T_{0} . C .15 .1$. Three of 4 lines at second generation $\left(T_{1}\right)$ were Mendelian segregation based on PCR analysis indicated by the presence of specific band for hpt gene. The third lines are $T_{1}$.C.4.2, $T_{1}$.C.8.1, and $T_{1}$.C.13.1. Integration of $h p t$ gene as selectable marker in the genome suggest that oshox4 gene is also integrated into genome because both genes are from the same of T-DNA. 


\section{ACKNOWLEDGEMENT}

The authors thank to Dr. A.H Meijer and Dr Pieter B.F. Ouwerkerk for providing recombinant plasmid, Thank to Dr. Sigit Purwantomo and Dr. Satya Nugroho for discussion, advice, and financial support.

\section{REFERENCE}

Agalou, A., S. Purwantomo, E. Overnas, H. Johannesson, X. Zhu, A. Estiati, R.J. de Kam, P. Engstom, I.H. Slamet-Loedin, Z.Zhu, M. Wang. L. Xiong, A.H. Meijer, and P.B.F. Ouwerkerk. 2008. A genome wide survey of HD-Zip genes in rice and analysis of drought responsive family members. Plant Molecular Biology 66: 87-103.

Aldemita, R.R. and T.K. Hodges. 1996. Agrobacterium tumefaciens-mediated transformation of Japonica and Indica rice varieties. Plant. 199: 612-617.

Bashir, K., M. Rafiq, T. Fatima, T. Husnain, and S. Riazuddin. 2004. Hygromycin based selection of transformants in a local inbred line of Zea mays (L). Pakistan Journal of Biological Sciences 7: 318-323

Brasileiro, A.C.M., and F.J.L. Aragao. 2001. Marker genes for in vitro selection of transgenic plants. Journal of Plant Biotechnology 3: 113-121.

Bray, E.A., J. Bailey-Serres, and E.Weretilniyk. 2000. Response to abiotic stresses. In: Gruissem, W., B.B. Buchannan, and R. Jones (eds.). Biochemistry and Molecular Biology of Plants. Rocvkville: American Society of Plant Physiologists.

Deng, X., J. Philips, A.H. Meijer, F. Salamini, and D. Bartels. 2002. Characterization of five novel dehydration responsive homeodomain leucine zipper genes from resurrection plant Craterostigma plantagineum. Plant Molecular Biology 49: 601-610.

Ge, X., Z. Chu, Y. Lin, and S. Wang. 2006. A tissue culture system for different germplasms of indica rice. Plant Cell Report 25: 392-402.

Gorantla, M., P.R. Babu, V.B.R. Lachagari, A.F. Feltus, and A.H. Peterson. 2005. Functional genomics of drought stress response in rice: Transcript mapping of annotated unigenes of an indica rice (Oryza sativa L. cv. Nagina 22). Current Science 89: 469-514.

Hiei, Y. and T. Komari. 2006. Improved protocols for transformation of Indica rice mediated by Agrobacterium tumefaciens. Plant Cell Tissue and Organ Culture 85: 271-283

Hiei, Y., S. Otha, T. Komari and T. Kumashiro. 1994. Efficient transformation of rice (Oryza sativa L) mediated by Agrobacterium and sequence analysis of the boundaries of the T-DNA. Plant Journal 6: 271-282.

Hu, H., M. Dai, J. Yao, B. Xiao, X. Li, Q. Zhang and L. Xiong. 2006. Over-expressing a NAM, ATAF and CUC (NAC) transcription factor enhances drought resistance and salt tolerance in rice. PNAS 103: 12987-12992

Khanna, H.K. and S.K. Raina. 2002. Elite indica transgenic rice plants expressing modified crylA (c) endotoxin of Bacillus thuringiensis show enhanced resistance to yellow stem borrer (Scirpophaga incertulas). Transgenic Research 11: 411-423.
Lin, Y.J. and Q. Zhang. 2005. Optimising the tisuue culture conditions for high efficiency transformation of indica rice. Plant Cell Report 23: 540-547.

Matzke, M.A. and A.J.M. Matzke. 1995. How and why do plants inactivate homologous (trans) gene?. Plant Physiology 107: 679-685.

Meijer, A.H., E. Scarpella, E.L. Van Dijk, L. Qin, A.J.C. Taal, S. Rueb, S.E. Harrington, S.R. McCouch, R.A. Schiperoot, and J.H.C. Hoge. 1997. Transcriptional repression by oshox1, a novel homeodomain leucin zipper protein from rice. Plant Journal 11: 263-276.

Purwantomo, S. 2007. Karakterisasi Faktor Transkripsi HD-Zip untuk Toleransi Kekeringan dan Introduksi Gen-gen Penyandi Lintasan Biosintesis Asam Salisilat untuk Ketahanan Penyakit Blas pada Tanaman Padi. [Disertasi]. Bogor: Institut Pertanian Bogor.

Rodriguez, R.C., and C. Nottenburg. 2003. Antibiotic Resistance Genes and their Use in Genetic Transformation Especially in Plants. CAMBIA. http:www.cambiaip.org/whitepapers/Transgenic/Ab_resistance/ books/ whole.pdf

Sakuma, Y., K. Maruyama Y. Osakabe Y, M. Seki, K. Shinozaki, and K. Yamaguchi-Shinozaki 2006. Functional analysis of an Arabidopsis transcription factor, DREB2A, involved in drought responsive gene expression. The Plant Cell 18: 1292-1309

Scarpella, E., E.J. Simons, and A.H. Meijer. 2005. Multiple regulatory elements contribute to the vascular-spesific expression of the rice HD-Zip gene oshox1 in Arabidopsis. Plant Cell Physiology 46: 1400-1410.

Shinozaki, K. and K.Yamaguchi-Shinozaki. 1997. Gene expression and signal transduction in water stress response. Plant Physiology 115: 327-334.

Shinozaki, K. and K.Yamaguchi-Shinozaki. 2007. Gene networks involved in drought stress response and tolerance. Journal of Experimental Botany. 58: 221-227.

Slamet-Loedin, I.H., J.L. Wibowo, S.Hutajulu, dan W. Rahayu. 1997. Penggunaan dua strain Agrobacterium tumefaciens super virulen untuk kokultivasi tanaman padi pada cv. cisadane dan rojolele. Prosiding Konggres I dan Seminar IImiah PBPI. Surabaya, 12-14 Maret 1997.

Taylor, C.B. 1997. Comprehending cosuppression. The Plant Cell 9: $1245-1249$

Wünn, J., A. Kloti, P.K. Burkhardt, G.C.G. Biswass, K. Launis, V.A. Iglesias, and I. Potrykus. 1996. Transgenic Indica rice breeding line IR-58 expressing a synthetic crylA (b) gene from Bacillus thuringiensis provides effective insect pest control. Bio/Technology 14: 171-176.

Yamaguchi-Shinozaki, K and K. Shinozaki. 2001. Improving plant drought, salt and freezing tolerance by gene transfer of a single stress-inducible transcription factor. in: Rice Biotechnology: Improving Yield, Stress Tolerance and Grain Quality - No. 236. (Novartis 1998. Transgenic Elite Indica Rice Varieties, Resistant to Xanthomonas oryzae $p v$. oryzae. Foundation Symposium). Chichester: Wiley.

Zhang, J., R.J. Xu, M.C. Elliott, D.F. Chen. 1997. Agrobacteriummediated transformation of elite indica and japonica rice cultivars. Molecular Biotechnology 8: 223-231

Zhang, S., W.Y. Song, L. Chen, D. Ruan, N. Taylor, P. Ronald, R. Beachy and C. Fauquet. 1998. Transgenic elite indica varieties, resistant to Xanthomonas oryzae pv. oryzae. Molecular Breeding 4 (6): 551-558. 